Vol. 10 (3): 483-490 (2020)

\title{
CONSUMER'S PREFERENCE BETWEEN FARMED CATFISH AND WILD CATFISH IN SWALI, YENAGOA LOCAL GOVERNMENT AREA OF BAYELSA STATE, NIGER DELTA
}

\author{
Ngodigha Sabina Alatari $^{\mathbf{1}}$, Gbarabe Roland ${ }^{2}$, Moroyei Ebilade ${ }^{1}$, Eleke Ezekiel Victor ${ }^{1}$ \\ I*Isaac Jasper Boro College of Education, Department of Agricultural Education, \\ Sagbama, Bayelsa State, Nigeria; \\ ${ }^{2}$ North West University, Department of Agricultural Economics and Extension South Africa;
}

*Corresponding Author Ngodigha Sabina Alatari, email: alatari3004@gmail.com;

Received May 2020; Accepted June 2020; Published July 2020;

DOI: https://doi.org/10.31407/ijees10.308

\begin{abstract}
The purpose of this study is to find out consumers preference between farmed catfish and wild catfish in Swali inYenegoa, Bayelsa State. Questionnaire was designed with both opened and closed ended questions and distributed randomly to participants. Descriptive statistics, percentage and t-test was use to analyze the information. The results showed that there was no significant difference between farmed catfish respondents and wild caught catfish respondents. The people ate catfish every week because of the taste, flavour and texture. Farmed catfish respodents preferred the dried catfish while wild catfish repondents preferred the fresh catfish. Wild catfish were preferred by females and the Ijaw tribe. Respondants never considered nutritional value of the catfish. Nutritionally, wild catfish contains more omega 3 fatty acid while the farmed contained more omega 6 fatty acid dangerous to the health. It is therefore advisable to consume farmed catfish in moderation.
\end{abstract}

Keywords: catfish, consumer, farmed, fatty acid, preference, wild 